\title{
Analysis of the Existing Property Transfer System and Stamp Duty Procedure in Sri Lanka with Special Reference to Gampaha District
}




\title{
Analysis of the Existing Property Transfer System and Stamp Duty Procedure in Sri Lanka with Special Reference to Gampaha District
}

\author{
Dissertation Submitted to the \\ University of Sri Jayewardenepura \\ As a Partial Fulfillment for the
}

Requirements of the Final Examination of the

M.Sc. in Real Estate Management and Valuation Degree

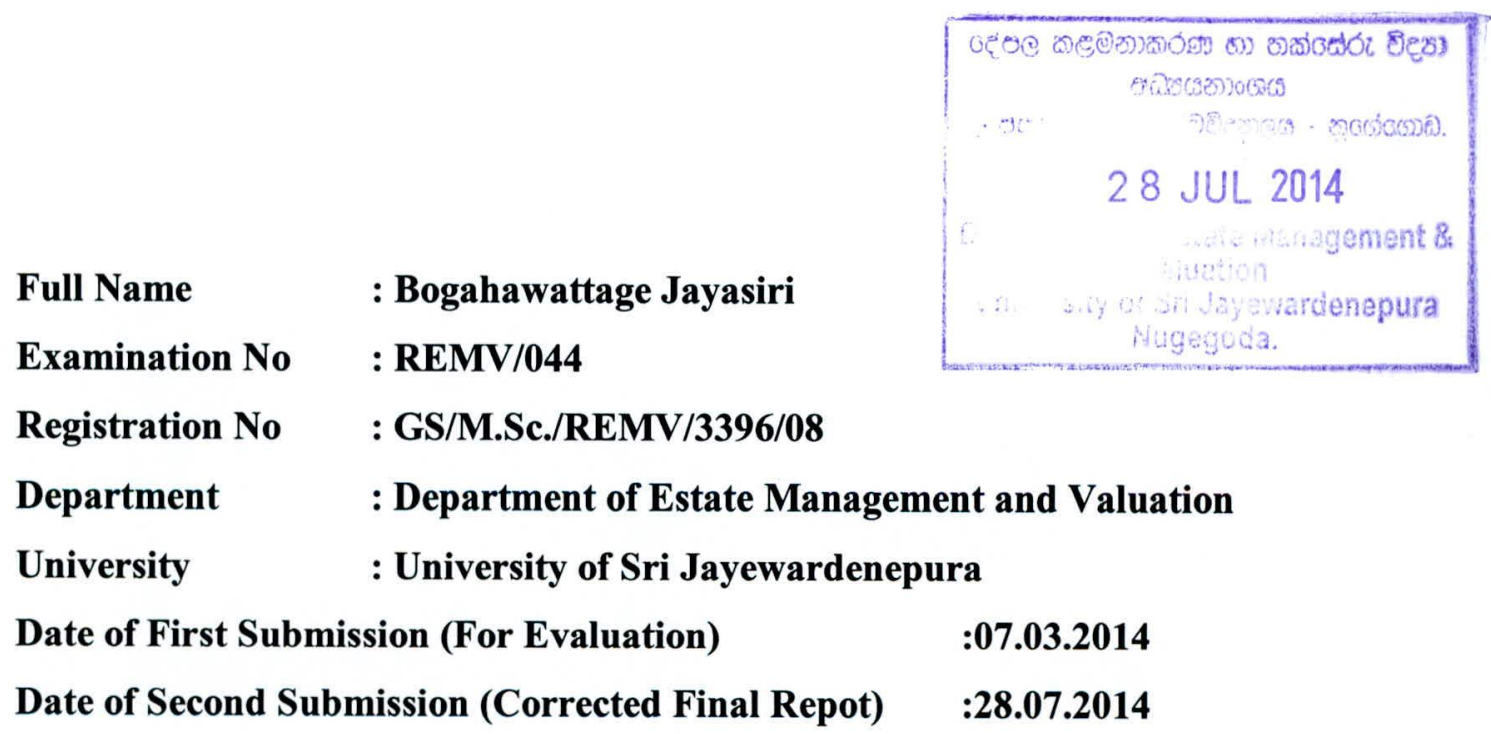




\section{Student's Declaration}

The work described in this dissertation was carried out under the supervision of $\mathrm{Mr}$. H.M. Premathillake Senior lecturer and any report on this has not been submitted in whole or in part to any university or any other institute for another degree /examination or any other purpose.

Bogahawattage Jayasiri

Index No. REMV/044

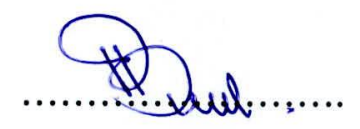

Signature

07.28.2014 


\section{Supervisor's Declaration}

Hereby, I certify that Mr. Bogahawattage Jayasiri (Registration No: GS/M.Sc./REMV/3396/08) duly completed the due corrections in the research titled "Analysis of the Existing property Transfer System and Stamp Duty Procedure in Sri Lanka with Special reference to Gampaha District" under my supervision and recommended to submission.

Also it is declared that, this final report has been completed according to the instructions and suggestions made by the board of examiners

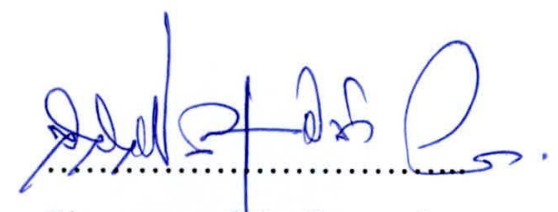

Signature of the Supervisor

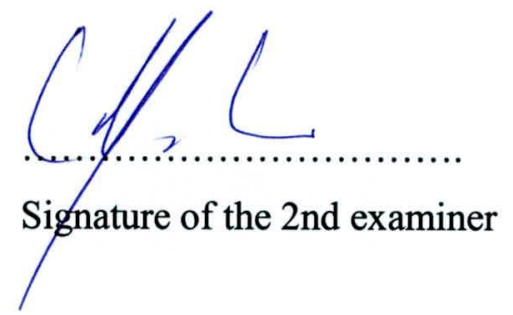

Signature and the official stamp of the Head 


\section{ACKNOWLEDGEMENT}

First, I would like to take my sincere thank to my Supervisor, Mr. H.M. Premathilaka, Senior Lecturer, for necessary guidance and towards to make this assignment successful. Then to the course coordinator Prof. R.G. Ariyawansa, Ms. Janaki Edirisinghe, Senior Lecturer, Ms. Padma Weerakoone, Senior Lecturer and Ms. Nishani Wickramaarachchi, Senior Lecturer for enormous encouragement. Finally to the Department of Real Estate Management and Valuation of University of Sri Jayewardenepura, Authors and Publishers of books, journals, periodicals.

Also, I highly appreciated the help, assistance and courage given by all my family members and friends to make this research project submitted to Department Real Estate Management and Valuation of Faculty of Management - Post Graduate Studies of University of Sri Jayewardenepura as a partial fulfillment of the requirement of the Master of Science Programme 2008/2010

Bogahawattage Jayasiri

Date: 07.28.2014 


\begin{abstract}
Payment of property transfer tax related when real estate transaction taken place. Basically the stamp duty payment takes place when ownership of property transactions taken place. This can be either the deed of transfer or deed of gift. Literature shows that there are different type's stamp duty payments in different countries. The main purpose of this study is to analyze Existing property Transfer System and Stamp Duty Procedure and introduce possible reforms for the payment stamp duty for property rights. Stamp duty payers were analyzed whether they are satisfied for the payment of stamp duty. Looking at opportunities to maximize the public benefit government considers development opportunities. Therefore it is essential to reform stamp duty transfer cost for land transactions. There are many researchers have carried out in this thematic area. A two way approach involving a questionnaire and a structured interview was applied in this study. The questionnaire survey was focused to collect perspectives from stamp duty payers whose paid stamp duty, this amount depend on consideration cost of the deed. Unit of analysis was affected beneficiaries. The sample selected was 51 affected parties who resolved their issue during the year 2011-2012. Out of the sample of 51 affected was selected covering from the area of Gampaha District was employed for this purpose and the analysis was done based on those completed questionnaires using Statistical Package for Social Science (SPSS) computer software. 20 Structured interviews from the professionals were held to ascertain their opinions on steps whichever necessary to identify the problems of stamp duty payment and possible reforms. Findings of the study indicate that undervalue of stamp duty payment and there is a requirement of a reform for stamp duty structure for transfer of ownership of property. Detailed data were collected from 3 case studies to analyses the percentage total cost incurred during property transaction. The total cost incurred were $8.76 \%, 8.81 \%$ and $8.91 \%$ on consideration cost of Rs. 1,0000,000/-, Rs, 1,500,000/- and 2,000,000 respectively. On average this cost was $8.82 \%$ from the total consideration amount. The key findings of this research will assist the policy makers to identify and introduce a suitable reform for stamp duty. Reducing this amount will lead to create an active property market.
\end{abstract}

Key Words: Stamp Duty, Property Transfer Tax, Deed Registration 


\section{TABLE OF CONTENTS}

$\begin{array}{ll}\text { Acknowledgement } & \text { i } \\ \text { Abstract } & \text { ii } \\ \text { Table of Contents } & \text { iii } \\ \text { List if Tables } & \text { vii } \\ \text { List if Maps } & \text { viii } \\ \text { List of figures } & \text { viii } \\ \text { List of Appendices } & \text { viii } \\ \text { Abbreviations } & \text { ix }\end{array}$

\section{Contents}

\section{CHAPTER ONE}

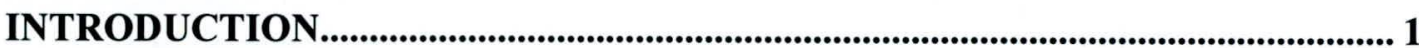

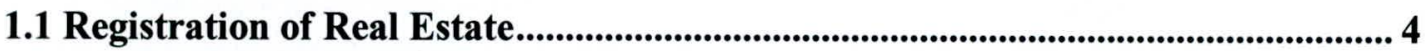

1.2. Stamp Duty and Transfer Tax System on Property in Sri Lanka ........................ 7

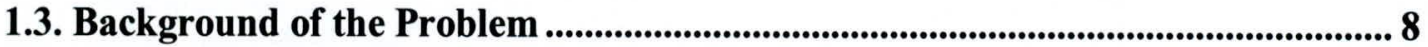

1.4. Background and Justification of the Problem......................................................... 12

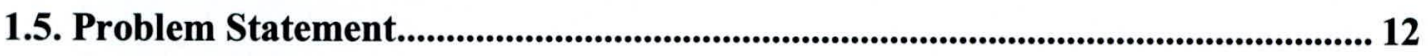

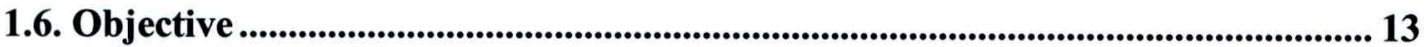

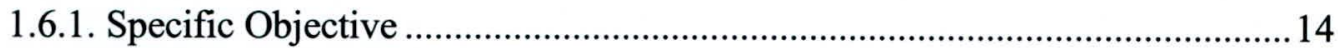

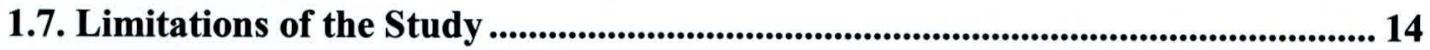

1.8. Significance of the Research ...................................................................................... 14

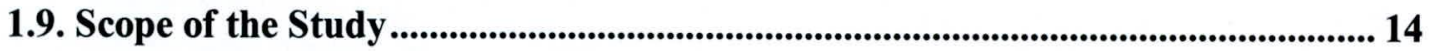

1.10. Organization and Preview of the Thesis ........................................................... 15

\section{CHAPTER TWO}




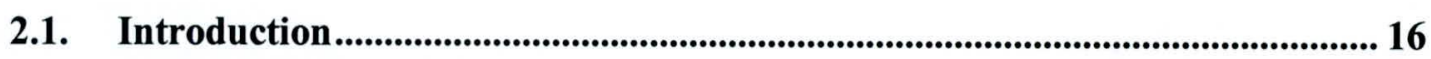

2.2. Review of Concepts and Literature ................................................................. 16

2.2.1. Meaning of tax and characteristics of a good tax system .......................... 18

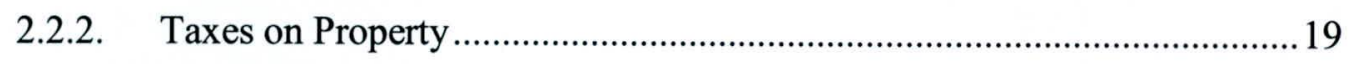

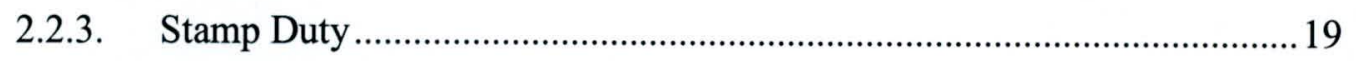

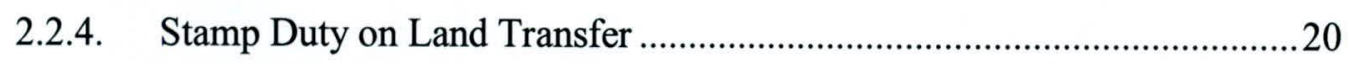

2.2.5. History of the Land Transfer Laws in Sri Lanka.......................................20

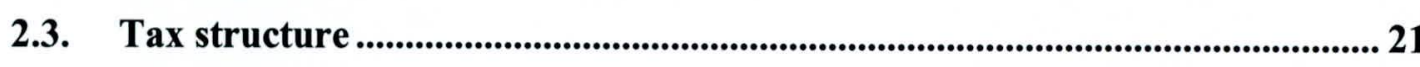

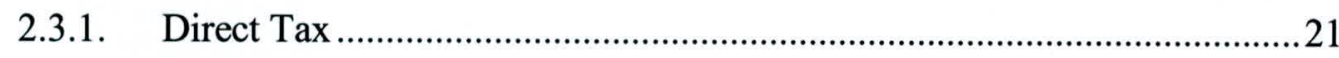

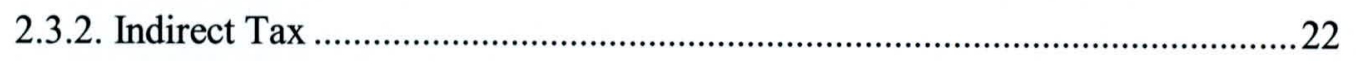

2.3.3. Tax Concessions for Qualifying Activities ...................................................22

2.3.4. General other concessions for BOI enterprises ..............................................2 23

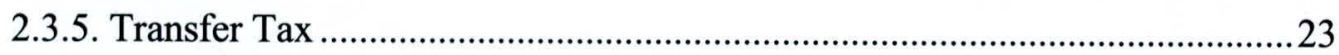

2.3.6. Stamp Duty on Purchasing a Property ...........................................................2 23

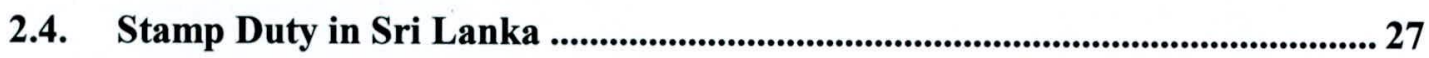

2.5. Relevant Gazette Notifications........................................................................... 27

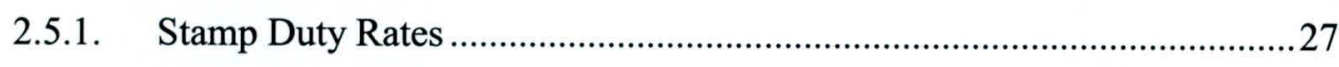

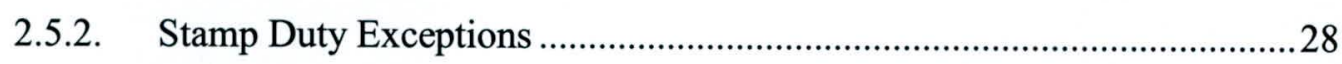

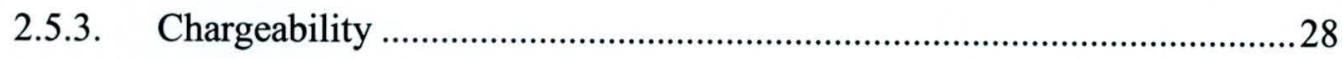

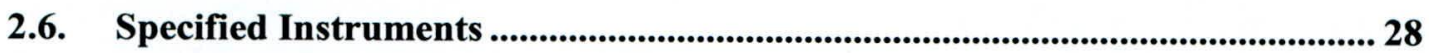

2.7. Mode and Time of payment of Stamp Duty ........................................................ 28

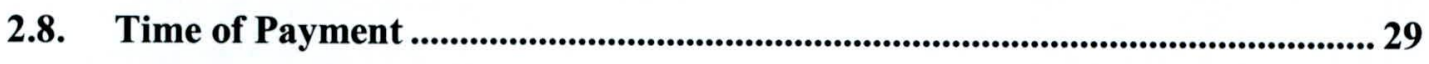

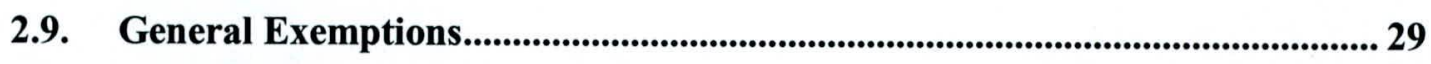

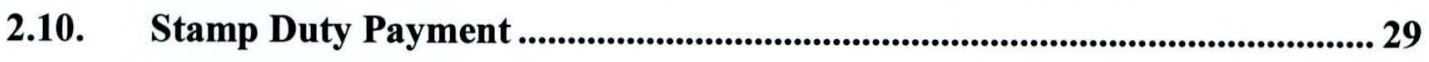

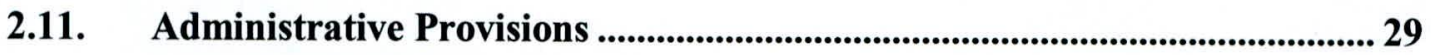

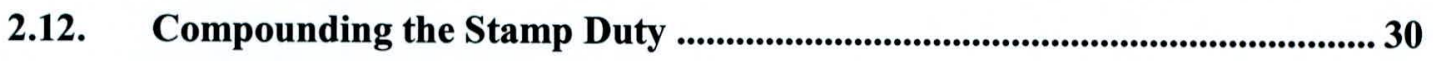

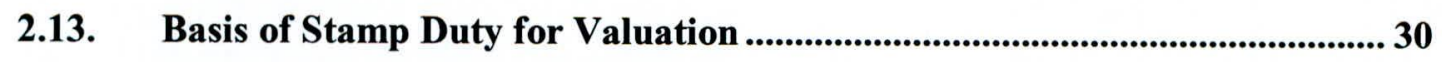

2.14. Determination of Market Value in Sri Lanka ............................................... 34

2.15. Valuation Methods to Determine the Stamp Duty .......................................... 34

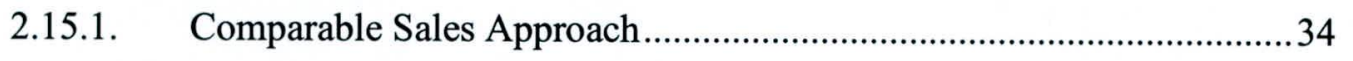


2.15.2. Income Capitalization Approach .......................................................... 35

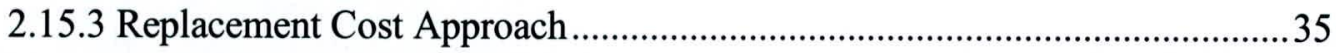

2.16. Valuation Methods Applied in Sri Lanka ..................................................... 35

2.16.1. Elements of Market Value …................................................................ 35

2.16.2. Market Approach - Comparison Method ................................................36

2.16.3. Income Approach - Investment Method.................................................36

2.16.4. Developers Approach - Residual Method ................................................37

2.16.5. Income Approach - Profits or Accounts Method ....................................37

2.16.6. Cost Approach - Contractor's Method .................................................... 37

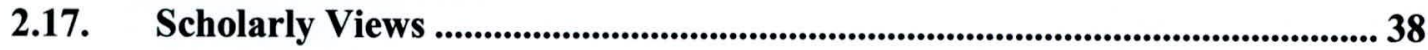

\section{CHAPTER THREE}

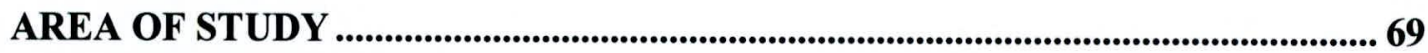

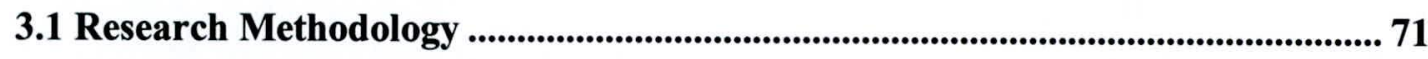

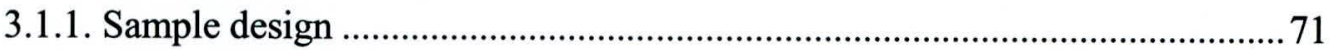

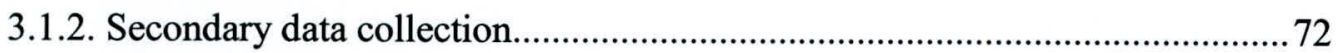

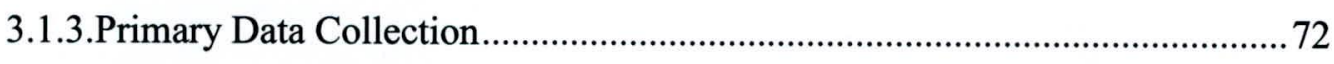

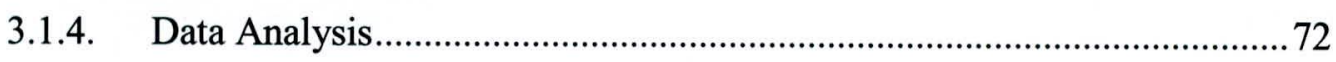

\section{CHAPTER FOUR}

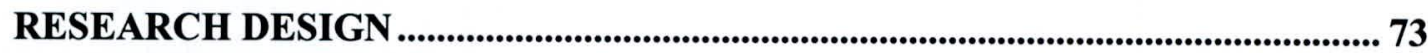

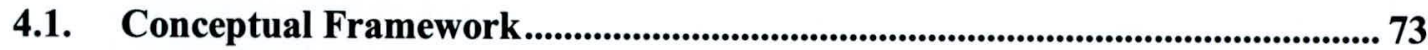

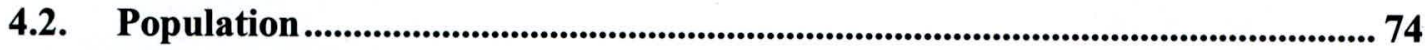

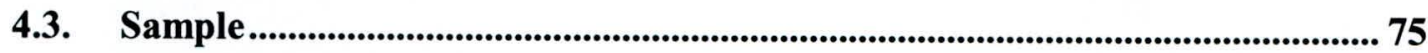

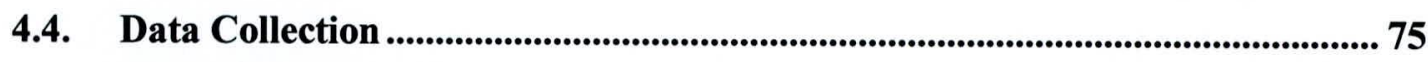

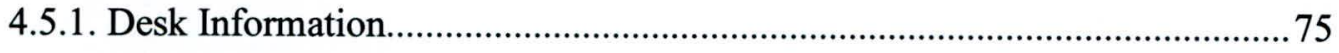

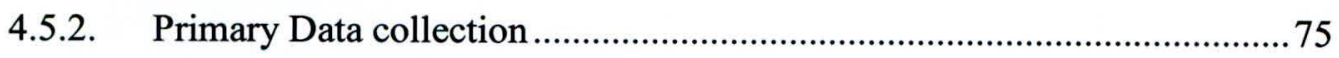

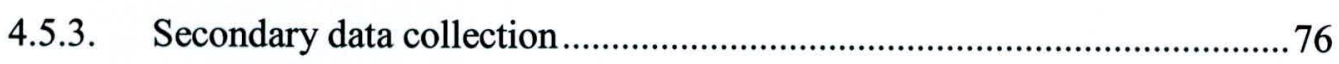

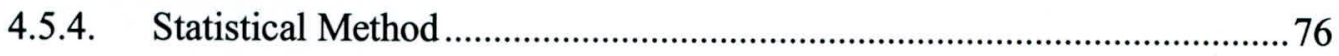




\section{CHAPTER FIVE}

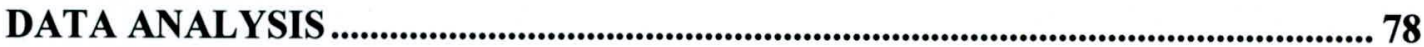

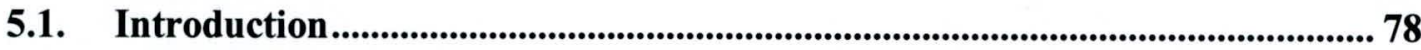

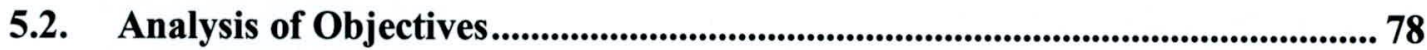

5.2.1. Percentage Appraisal Error......................................................................... 79

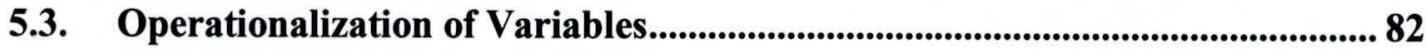

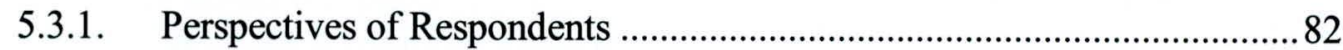

5.3.2. Validation of Measurement Properties ....................................................... 85

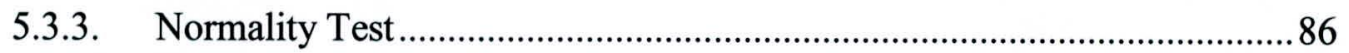

\section{CHAPTER SIX}

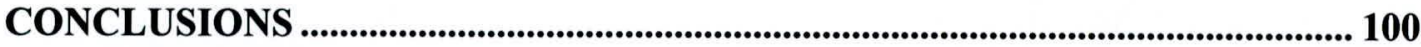

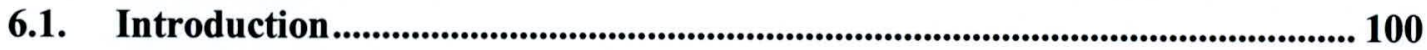

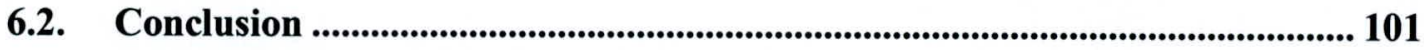

6.3. Recommendation and Policy Implications ................................................... 107

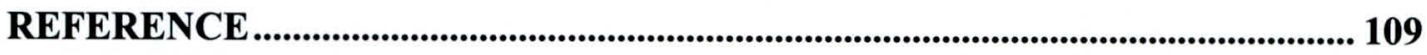

Annexure 1: Factor analysis and reliability test ............................................................ 113

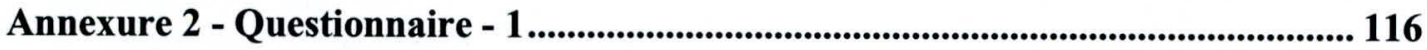

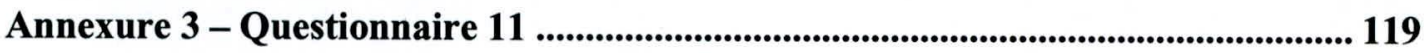




\section{LIST OF TABLES}

Table

5.1

5.2
Description

Page

Total Divisional Secretariat Divisions

69

70

Total Population in Gampaha District

Categories of Absolute Percentage Appraisal Errors in selected Local Authorities

Absolute Percentage Appraisal Errors in Divisional Secretariat

Division levels

Total Cost as a Percentage of Consideration for Selected

Transitions

Cross Tabulation against Groups and Grama Niladari Division

Cross Tabulation of Grama Niladari Division - Issue

Type against Property type

83

Cross Tabulation of Property type against Issue type

85

Test Statistics - Frequencies

85

Test Statistics- Cost consideration

86

Tests of Normality-Perspectives of Respondents

(Professionals and affected parties)

87

88

89

Group Cross tabulation of Property type against Issue type

89

90

90

Standardized Canonical Discriminant Function Coefficients 90 Functions at Group Centroids 91

Correlations

Professional Response from Selected Land Registry Area

Test Statistics

97

Content Analysis

98 
LIST OF MAPS

Map

Description

Page

3.1

Area of the Research Focus

71

\section{LIST OF FIGURES}

Map

Description

Page

5.1

Total Cost as a percentage of Consideration

82

5.2

Issue Type against Property type

84

\section{LIST OF APPENDICES}

Annexure

01

02

03

\section{Description}

Factor analysis and reliability test

Questionnaire - 1

Questionnaire-2
Page

113

116

119 


\section{Abbreviations}

\begin{tabular}{ll} 
AD & After Death \\
BC & Before Christ \\
CGIR & Corporate Governance and International Review \\
CGT & Capital Gains Tax \\
DT & Deed Tax \\
ET & Estate Tax \\
GPG & Global Property Guide \\
GST & Good and Services Tax \\
GT & Gift Tax \\
HIA & Health Impact Assessment \\
HMRC & Her Majesty Revenue\& Customs \\
HT & House Tax \\
IT & Income Tax \\
IVSC & International Valuation Standards Council \\
OECD & Organization for Economic Corporation and Development \\
LA & Land Acquisition \\
LBTT & Land and Building Transaction Tax \\
LVT & Land Value Tax \\
LVIT & Land Value Incremental Tax \\
PEIT & Profit-Seeking Enterprise Income Tax \\
RETI & Real Estate Transparency Index \\
SEC & Section \\
ST & Stamp Tax \\
SDLT & Stamp Duty Land Tax \\
UDIA & Urban Development Impact Assessment \\
UK & United Kingdom \\
USA & United States of America \\
USD & United States Dollar \\
VAT & Value Added Tax \\
\hline
\end{tabular}




\section{CHAPTER ONE}

\section{INTRODUCTION}

With the effect of globalization, internationalization of property market is an unavoidable context in any country in the world. Real estate represents a significant share of the physical capital stock of the economy and it helps to generate income for other source too. Study of real estate is a very broad which includes evaluation of real estate market, characteristics of real estate, efficiencies \& inefficiencies of real estate, issues related to real property market.

Real estate which is scarce natural resources plays a key role in development. Land is the foundation of all forms of human activity. It is the means of life without which human beings could never have existed and on which their continued existence and progress depend. Also land is a factor of production. For any physical development to take place there should be a land as the priority requirement. There are many proposed infrastructure development projects in the pipeline now in Sri Lanka. Much of investors' incentive for the development, maintenance and improvement of land resources is rooted in the concept of property rights. This concept involves complex of rules and procedures under which property is owned, leased, mortgaged and legally transferred to others (Premathilaka, 1998).

Since land is the base for development it should be made available for the right use at right time in the right location in right quantity at right price. Stamp duty on transfer of ownership if real estate transfers tax on the market value of the property as at date of transfer of ownership recent property transaction prices. Therefore, efficient market-based allocation of land is evidently a necessity for development and community life.

This study mainly focuses on assessment and payment of stamp duty and transfer tax at the time of transfer of ownership of real estate in Sri Lanka. The broad objective of this study is to examine the existing system of assessment and payment of stamp duty 
and transfer tax at the time of transfer of ownership of real estate and the impact of land transfer cost on marketability of land.

Stamp duty is a tax that is levied on documents. Historically, this included the majority of legal documents such as cheques, receipts, military commissions, marriage licenses and land transactions. A physical stamp (a revenue stamp) had to be attached to or impressed upon the document to denote that stamp duty had been paid before the document was legally effective. More modern versions of the tax no longer require an actual stamp.

Much of investors' incentive for the development maintenance and improvements of resources is rooted in the concept of property rights. At present with $84 \%$ of total the state dominates land ownership in Sri Lanka. Agricultural land accounts for approximately 2.79 million hectares or about $43 \%$ of total land mass, of this $53 \%$ is owned by the state, but farmed by private farmers under varying tenure agreements (World Bank, 1996)

Prior to the British colonization, the whole land of the country was managed \& conserved by the king. The king was recognized as the trustee of the land but not the owner of the land. After the country become a British colony, all lands become under the control of British crown. During the colonial period they introduce new real estate development including plantation, commercial developments residential property developments and development of infrastructure facilities etc. Thereafter, various changes have been experienced with effect of changing political, legal, economic and social circumstances in connection with the tenure of land and real estate. When the united front government came in to power in 1970-1977, national economy become major changes. During the period of 07 years, two land reform Acts were passed in 1972 and 1975 that vested a more than million acres of private land with the state. Enactment of Rent Act No. 07 of 1972 and the ceiling on Housing Property Law No.1 of 1973 are some other legal impacts on the development of land \& property tenure and ownership. Market system was totally inactive during the period and which discouraged private investors to invest more on landed properties. 